\title{
SEISMIC WAVES VELOCITIES INFERRED FROM THE SURFACE WAVES DISPERSION IN THE MALÉ KARPATY MOUNTAINS, SLOVAKIA
}

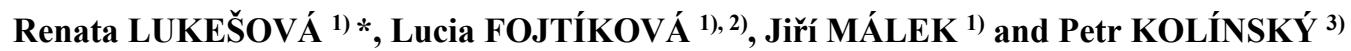 \\ 1) Institute of Rock Structure and Mechanics, The Czech Academy of Sciences, V Holešovičkách 41, 18209 Prague 8, Czech Republic \\ 2) Earth Science Institute, Slovak Academy of Sciences, Dúbravská cesta 9, 840 05, Bratislava, Slovakia \\ 3) Department of Meteorology and Geophysics, University of Vienna, 1090 Vienna, Althanstraße 14, Austria
}

*Corresponding author's e-mail: lukesova@irsm.cas.cz

\section{ARTICLE INFO}

\section{Article history}

Received 31 August 2019

Accepted 16 October 2019

Available online 7 November 2019

Keywords:

Surface waves

Joint inversion of Love and Rayleigh waves

1-D velocity model

Malé Karpaty

\begin{abstract}
The study area of Western Carpathians belongs to one of the most seismically active regions in Slovakia, where the available velocity models are not precise enough for accurate location and determination of focal mechanism. To improve the uppermost part of the currently used models, seismic surface wave data from two blasts in the quarry Rohožník, recorded at the MKnet local seismic network, were analyzed. Group velocity dispersion curves of Rayleigh and Love waves were determined by the frequency-time analysis. A mean group velocity dispersion curve for Love and Rayleigh waves for the central part of the MKnet network was settled and consequently joint inversion, for the period range $0.9-2.7 \mathrm{~s}$, was performed to obtain a 1-D velocity model using the isometric method. The 11-layered model extends to depth of $2.5 \mathrm{~km}$ and indicate increase of the velocities from the surface down to the depths of $0.9 \mathrm{~km}$. Then, velocities slightly decrease. The minimum of the low-velocity zone is at the depth of $1.8 \mathrm{~km}$ after which the velocities moderately increase to the velocity of the halfspace with $v_{P}=5.35 \mathrm{~km} / \mathrm{s}$ and $v_{S}=2.96 \mathrm{~km} / \mathrm{s}$.
\end{abstract}

\section{INTRODUCTION}

The Western Carpathians is one of the most seismically active regions in Slovakia. It consists of Malé Karpaty Mountains (Little Carpathians) and Brezovské Mountains that are separated by the Váh valley filled with Neogene sediments. The region of Malé Karpaty is located in the transition zone between the Eastern Alps and the Western Carpathians. It represents northwestern part of the Danube Basin and separates the Danube and Vienna basins. The Malé Karpaty Mountains represent a typical core mountain of the Tatricum Unit situated in Western Slovakia, a SW part of the Central Western Carpathians. The granitic massifs are dominant parts of the Malé Karpaty Mts. forming their pre-Alpine basement in the southern and central part. The crystalline basement rocks (granites and crystalline schists) are overlain by the Late Paleozoic and mainly the Mesozoic sedimentary (cover) sequences, Mesozoic nappes (Fatricum and Hronicum Units) and often also directly by the Cenozoic (Paleogene, Neogene) sediments. Brezovské Karpaty Mountains are mostly formed by Mesozoic sediments (Hronicum Unit), Upper Cretaceous, Paleogene and Neogene sediments in the northern part. More tectonic and geological descriptions of the area can be found in the works of Plašienka et al. (1991); Plašienka et al. (1997); Polák et al. (2011); Bezák et al. (2014); Hók et al. (2015); Marko et al. (2017), etc.

In the last several decades, only weak seismic events have been observed, but remarkable historical seismicity has been documented in this region. The last strong earthquake with magnitude 5.7 occurred at Dobrá Voda on January 9, 1906.

Little Carpathians source zone is monitored by local seismic network MKnet (Fig. 1). The network has been operating since 1985, and its configuration and equipment have passed through several significant improvements. The primary objective of the network is detailed monitoring of seismic activity in the vicinity of nuclear power plant Jaslovské Bohunice (EBO).

Tectonic and geological conditions of the region are complex. Despite intensive seismic monitoring, available velocity models are not precise enough and insufficient for advanced seismological studies. The 3-D velocity model (Fig. 2) was created by Geofyzika Brno (1985). However, it was intended only for the area surrounding the nuclear power plant EBO. It covers a very limited area.

Several simplified 1-D models have been created based on the previous 3-D model (top panels, Fig. 3) for calculating focal mechanisms and estimation of location errors of the seismic network MK-net 


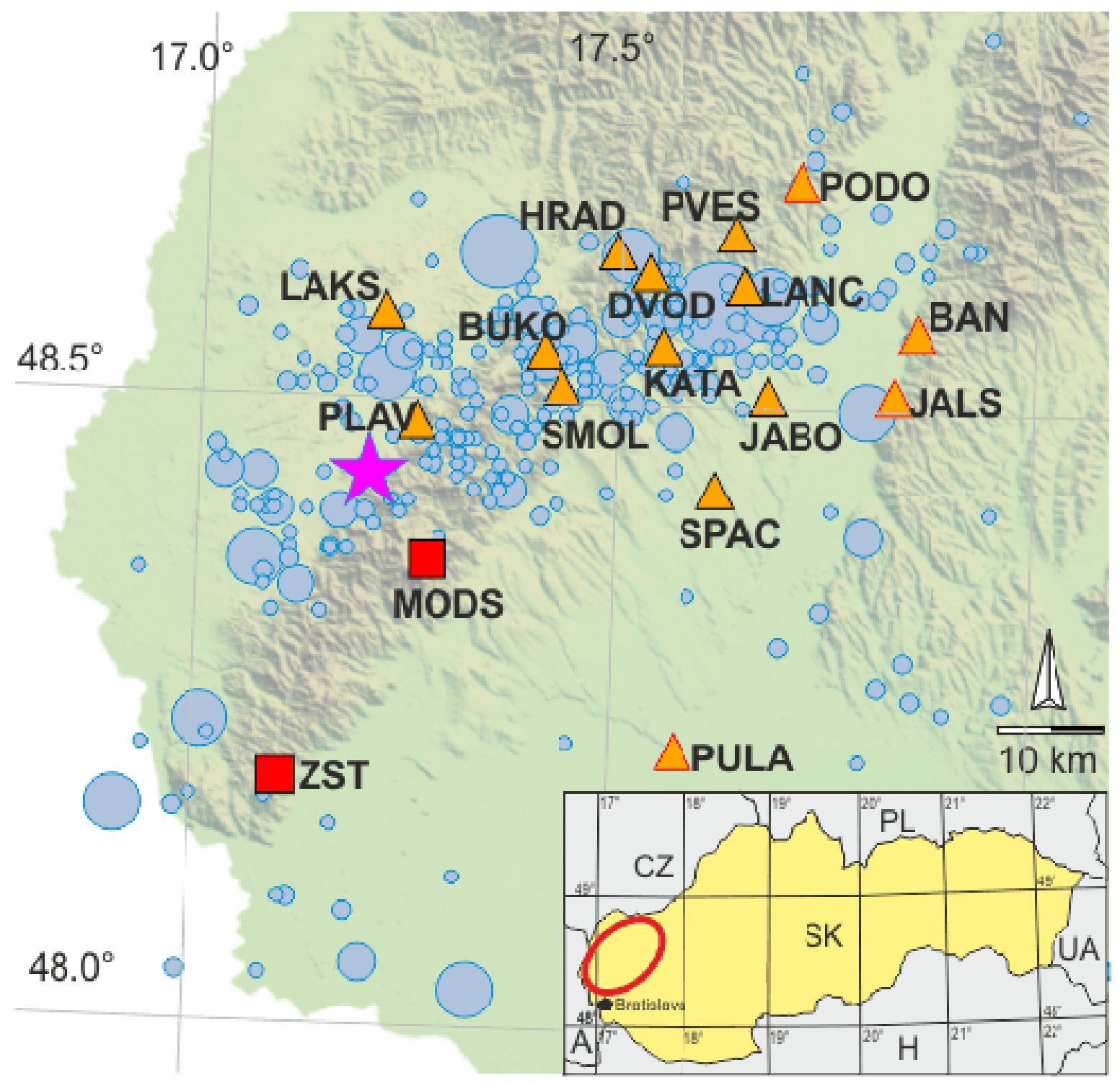

Fig. 1 The studied region, seismic stations and earthquake epicenters $1930-2018$. The MKnet network consists of 16 stations (red squares and orange triangles): stations ZST and MODS belong to the Slovak national network of seismic stations - DOI: 10.14470/FX099882; 4 stations (orange triangles with red frames) are stations operated in cooperation of Institute of Rock Structure and Mechanics CAS, Earth Sciences Institute SAS and Progseis Ltd. and 11 stations (orange triangles with black frames) belong to the local seismic network that monitors the area surrounding the nuclear power plant Jaslovské Bohunice and these stations are operated by Progseis Ltd. Station JABO is inside the power plant area. Grey circles symbolize earthquakes with magnitude $0 \leq \mathrm{M} \leq 5.0$, respectively. The purple star represents the blast in the Rohožník quarry. Inset shows a broader region.

(Fojtíková et al., 2010; Fojtíková et al., 2016). Jechumtálová and Bulant (2014) studied the effects of 1-D and 3-D velocity models on moment tensors inversions. All of the 1-D models consist of several layers with velocities increasing with depth until reaching a halfspace at depth of $27 \mathrm{~km}$ which has a P-wave velocity of $8.20 \mathrm{~km} / \mathrm{s}$ and S-wave velocity of $4.69 \mathrm{~km} / \mathrm{s}$. Model DV1 represents an average model for the whole area; it consists of five layers above the halfspace. Model DV-Fast is used for stations HRAD and KATA and represents the model with the highest velocities in the upper parts. It consists of seven layers above the halfspace. Six uppermost layers have higher velocities than DV1. Model DV-Slow is used for the stations SPAC and JABO, which are situated in the Neogene sedimentary basin. Top six layers have lower velocities than DV1. The last layer (starting at the depth of $10.0 \mathrm{~km}$ ) and the halfspace (at depth of $27 \mathrm{~km}$ ) have the same velocities for all models. Theoretical dispersion curves of group velocities for a fundamental and first higher mode of both Love and Rayleigh waves for all aforementioned three models were computed with the help of the Geopsy software (www.geopsy.org) - for 


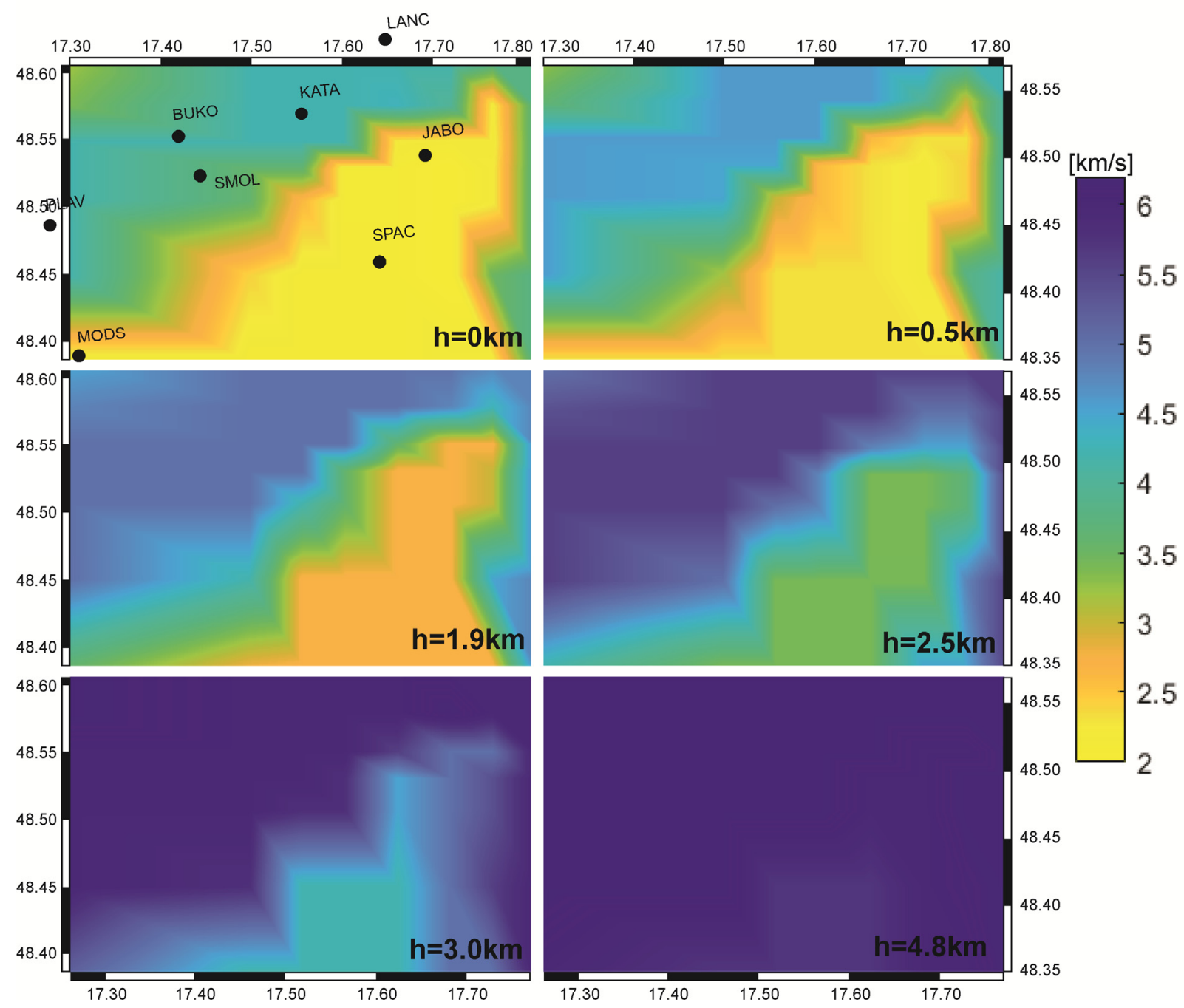

Fig. 2 3-D velocity model (P waves) created by Geofyzika Brno (1985) displayed for depths: $0 \mathrm{~km}, 0.5 \mathrm{~km}$, $1.9 \mathrm{~km}, 2.5 \mathrm{~km}, 3.0 \mathrm{~km}$ and $4.8 \mathrm{~km}$. The yellow color represents slow velocity structure with the velocity as low as $2 \mathrm{~km} / \mathrm{s}$ at the surface; the blue color represents faster structures.

details see Di Giulio (2006), Wathelet et al. (2008) and Wathelet et al. (2018). The resultant dispersion curves are depicted on the bottom panels of Figure 3.

The main objective of the present paper is to propose a new, layered $1 \mathrm{D}$ velocity model, which can be used to improve the uppermost part of the current models. Our model, titled as MKMt model, extends to $2.5 \mathrm{~km}$ depth. It is derived from the joint inversion of the Rayleigh and Love wave group velocity dispersion curves inferred from quarry blasts and is valid for central part of the MK-net (area covered with stations BUKO, DVOD, HRAD, KATA, LANC, PODO, PVES and SMOL).

\section{DATA}

To improve the existing seismic model of the region the following seismic experiment was proposed and executed. The experiment was based on the inversion of group velocities of surface waves. Two quarry blasts (approximately 12 ton of TNT each; 2015-08-10 and 2015-09-02) in Rohožník quarry were used as a source of seismic waves. The exact positions of the blasts are known.
The quarry blasts were recorded at all stations of MKnet. The seismic network during the experiment consisted of 17 seismic stations (see Fig. 1). Parameters of the seismic stations are listed in Table 1. All recordings are continuous with a sampling frequency of $100 \mathrm{~Hz}$ and data are transmitted in real-time. Example of measured seismograms can be found in Figure 4.

\section{METHODS}

\subsection{DETERMINATION OF HYPOCENTRAL TIME $T_{0}$}

The hypocentral time $t_{0}$ can be determined from onset times of $\mathrm{Pg}\left(t p^{N}\right)$ and $\mathrm{Sg}\left(t s^{N}\right)$ at the nearest station. In our case, the nearest station is PLAV, which is located at the distance of $6.09 \mathrm{~km}$ and $6.44 \mathrm{~km}$ from blast 1 and blast 2, respectively. The Pg onset at the PLAV station is very clear, and $t p^{N}$ is determined very precisely with an error equal to the sampling period $0.01 \mathrm{~s}$. The time $t s^{N}$ is determined within an error of five samples, equivalent to $0.05 \mathrm{~s}$. The simplest method for determination of $t_{0}$ is using the equation: 

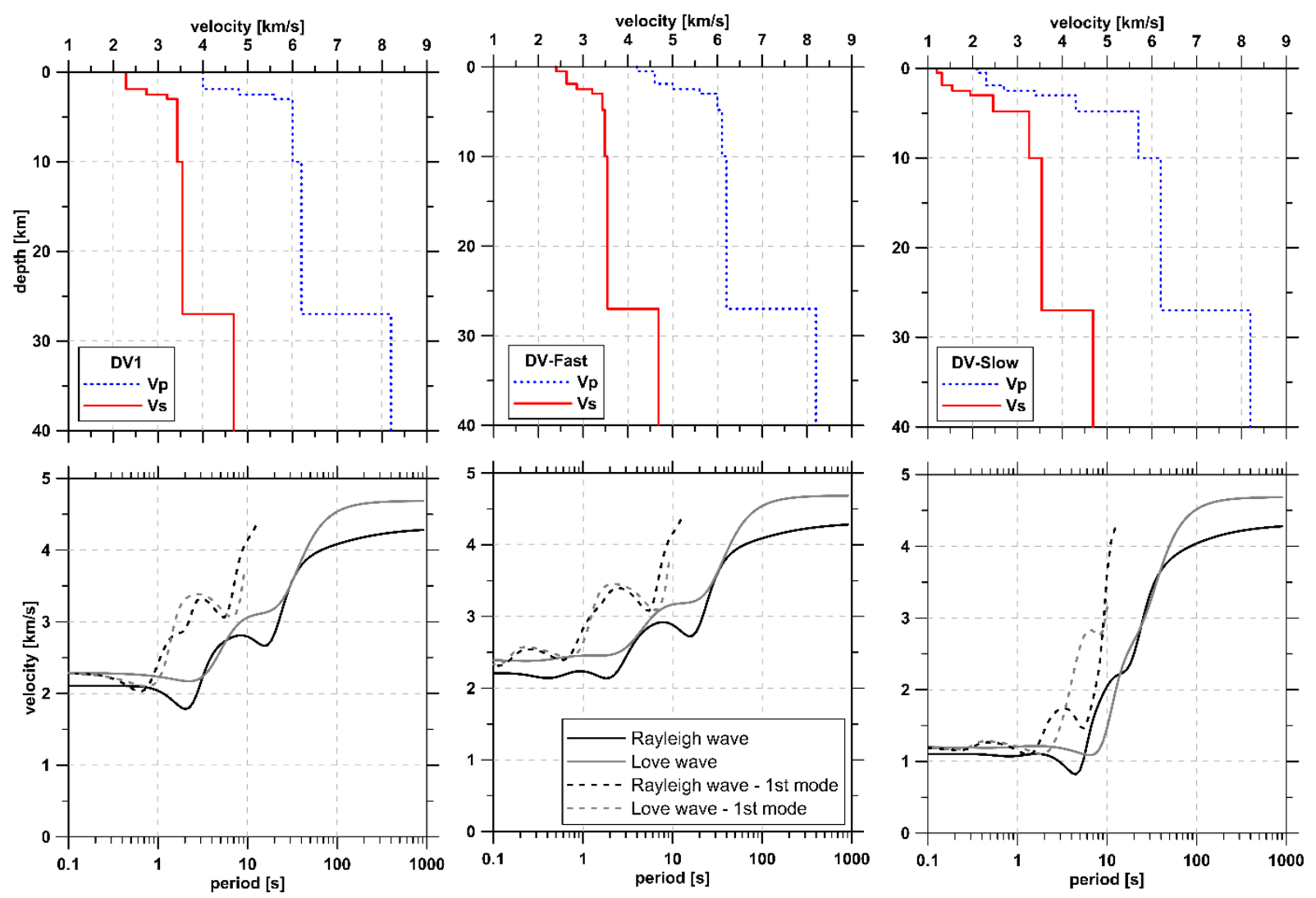

Fig. 3 A set of simplified 1-D models has been created based on the 3-D model (top panels) and their corresponding group velocity dispersion curves of a fundamental and first higher mode of Rayleigh and Love waves were calculated (bottom panels).

Table 1 Parameters of seismic stations MKnet: geographical coordinates (Lat and Lon), sensor, instrumental low frequency corner (freq) and relative position of quarry blasts $\mathrm{O} 1$ and $\mathrm{O} 2$ with respect to each station: epicentral distance $(\Delta \mathrm{x})$ and backazimuth (BAZ).

\begin{tabular}{|c|c|c|c|c|c|c|c|c|}
\hline \multirow[t]{2}{*}{ name } & \multirow[t]{2}{*}{ Lat $\left[{ }^{\circ} \mathrm{N}\right]$} & \multirow[t]{2}{*}{ Lon $\left[{ }^{\circ} \mathbf{E}\right]$} & \multirow[t]{2}{*}{ Sensor } & \multirow[t]{2}{*}{ freq } & \multicolumn{2}{|c|}{$\begin{array}{c}\text { O1 - quarry blast } \\
2015-08-10\end{array}$} & \multicolumn{2}{|c|}{$\begin{array}{c}\text { O2 - quarry blast } \\
2015-09-02\end{array}$} \\
\hline & & & & & $\Delta \mathbf{x}[\mathbf{k m}]$ & BAZ & $\Delta x[\mathbf{k m}]$ & BAZ \\
\hline BAN & 48.56 & 17.86 & Lennartz & $1 \mathrm{~s}$ & 49.97 & 254.73 & 50.26 & 254.47 \\
\hline BUKO & 48.54 & 17.41 & Guralp CMG-40T & $10 \mathrm{~s}$ & 18.62 & 233.84 & 18.98 & 233.49 \\
\hline DVOD & 48.61 & 17.53 & Guralp CMG-40T & $10 \mathrm{~s}$ & 30.23 & 233.35 & 30.59 & 233.14 \\
\hline HRAD & 48.62 & 17.49 & Guralp CMG-40T & $10 \mathrm{~s}$ & 29.16 & 226.92 & 29.53 & 226.78 \\
\hline JABO & 48.50 & 17.70 & Guralp CMG-40T & $1 \mathrm{~s}$ & 36.85 & 260.72 & 37.12 & 260.32 \\
\hline JALS & 48.51 & 17.83 & Guralp CMG-40T & $30 \mathrm{~s}$ & 46.89 & 260.90 & 47.16 & 260.58 \\
\hline KATA & 48.55 & 17.55 & Guralp CMG-40T & $10 \mathrm{~s}$ & 28.08 & 245.49 & 28.41 & 245.12 \\
\hline LAKS & 48.57 & 17.22 & Guralp CMG-40T & $10 \mathrm{~s}$ & 14.26 & 182.75 & 14.57 & 183.56 \\
\hline LANC & 48.60 & 17.65 & Guralp CMG-40T & $10 \mathrm{~s}$ & 36.91 & 242.53 & 37.25 & 242.27 \\
\hline MODS & 48.37 & 17.28 & STS2 & $100 \mathrm{~s}$ & 9.48 & 326.64 & 9.35 & 324.47 \\
\hline PLAV & 48.48 & 17.26 & Guralp CMG-40T & $10 \mathrm{~s}$ & 6.03 & 222.03 & 6.40 & 221.69 \\
\hline PODO & 48.68 & 17.71 & Guralp CMG-40T & $30 \mathrm{~s}$ & 45.85 & 234.83 & 46.21 & 234.68 \\
\hline PULA & 48.23 & 17.58 & Lennartz & $1 \mathrm{~s}$ & 36.76 & 311.24 & 36.73 & 310.65 \\
\hline PVES & 48.63 & 17.64 & Guralp CMG-40T & $10 \mathrm{~s}$ & 38.18 & 236.61 & 38.54 & 236.42 \\
\hline SMOL & 48.51 & 17.43 & Guralp CMG-40T & $10 \mathrm{~s}$ & 18.38 & 245.12 & 18.71 & 244.56 \\
\hline SPAC & 48.43 & 17.62 & Guralp CMG-40T & $10 \mathrm{~s}$ & 30.71 & 272.18 & 30.93 & 271.60 \\
\hline ZST & 48.20 & 17.10 & SKD & $14 \mathrm{~s}$ & 28.64 & 15.59 & 28.29 & 15.33 \\
\hline
\end{tabular}



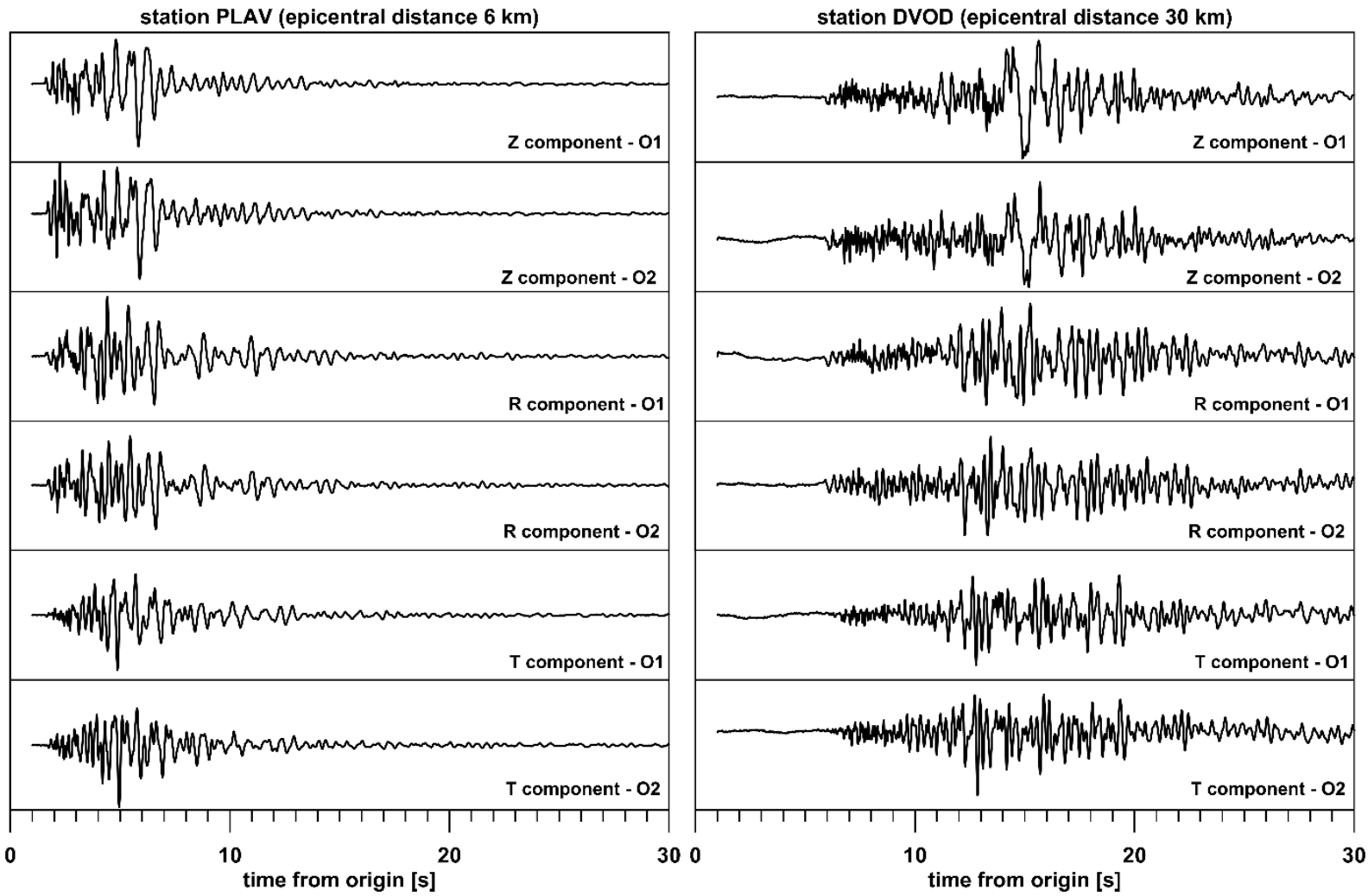

Fig. 4 Example of recorded seismograms at stations PLAV (station with minimal epicentral distance) and station DVOD (epicentral distance $30 \mathrm{~km}$ ) from both quarry blast O1 (2015-08-10) and O2 (2015-09-02) for vertical $(\mathrm{Z})$, radial $(\mathrm{R})$ and transversal $(\mathrm{T})$ component.

$t_{o}=t p^{N}-\frac{r}{v_{p}}$

where $r$ is the hypocentral distance and $v_{P}$ is the average Pg-wave velocity between the hypocenter and the nearest station.

However, the $v_{P}$ is a priori unknown, as we do not have a reliable model of the shallow velocity structure. Its value strongly depends on the local conditions. In this experiment, when epicentral distance of the nearest station is about $6 \mathrm{~km}$, and both the blast and the station are situated on limestone, a rough estimation of $v_{P}$ is $4.0 \pm 1.0 \mathrm{~km} / \mathrm{s}$, which gives us an error for $t_{0}$ of $\pm 0.4 \mathrm{~s}$.

A better estimate of $t_{0}$ can be obtained with the help of the time difference between $t s^{N}$ and $t p^{N}$ :

$t_{o}=t p^{N}-\frac{\left(t s^{N}-t p^{N}\right)}{(k-1)}$

where $k$ is the average value of $v_{P} / v_{S}$.

Note, that we do not need the epicentral distance using equation (2), so we can use this method even if the location of hypocenter is unknown. The parameter $k$ can be determined using the Wadati method (Wadati, 1933; Novotný et al., 2016). Let us denote arrival times of $\mathrm{P}$ and $\mathrm{S}$ waves at the i-th station $t p i$ and tsi. Assuming the parameter $k$ is constant, the relation between $t s i-t p i$ and $t p i$ is linear. We can construct this Wadati graph (Fig. 5) and determine the tangent, which corresponds to $k-1$. Using the Wadati method we determined:

$$
k=1.81 \pm 0.02
$$

And the time $t_{0}$ is

$t_{0}=12: 32: 28.73 \pm 0.10$ for $\mathrm{O} 1$ (blast 1 )

$t_{0}=09: 03: 45.99 \pm 0.11$ for O2 (blast 2)

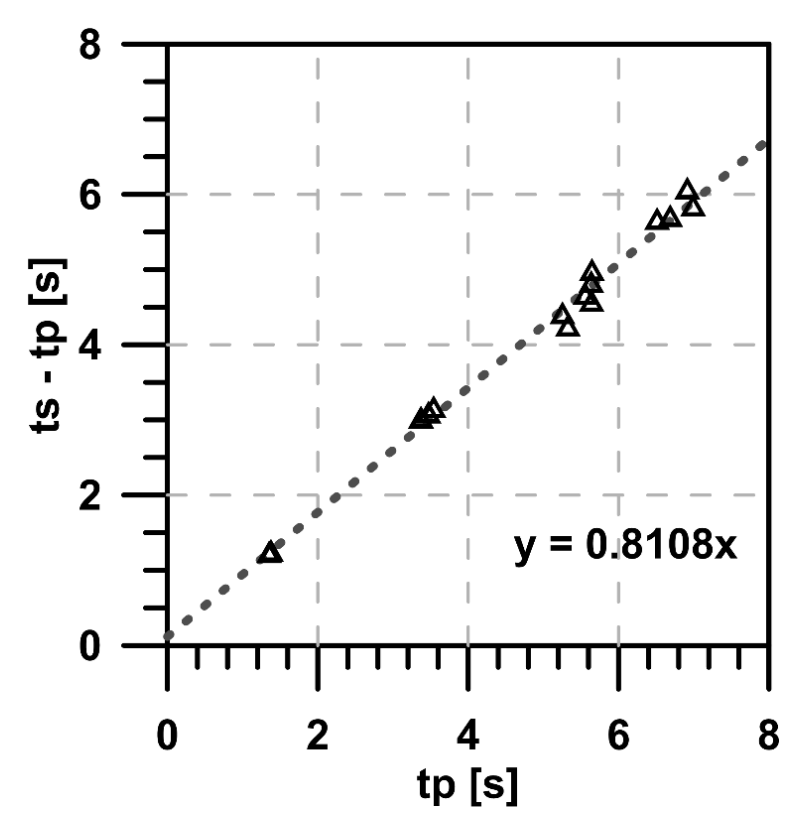

Fig. 5 Wadati graph (for both $\mathrm{O} 1$ and $\mathrm{O} 2$ quarry blasts) to determine $\mathrm{v}_{\mathrm{P}} / \mathrm{v}_{\mathrm{S}}$ ratio. 
Now, we can compute from (1) the value of $v_{P}=$ $3.9 \pm 0.3 \mathrm{~km} / \mathrm{s}$ for both blasts - which is consistent with our expectation.

\subsection{GROUP VELOCITY MEASUREMENT}

Surface wave analysis was done by the SVAL program (Kolínský, 2004). The SVAL program uses multiple filtering technique (Dziewonski et al., 1969). It is a standard method of the Fourier transform-based frequency-time analysis. Initially, the Fourier spectrum of the whole seismogram of a selected component is calculated. Then the spectrum is weighted by a set of Gaussian filters defined by their width and central frequency. The filters have a nonconstant relative resolution. Towards higher frequencies, the width of the filters is broader in the frequency domain to ensure more accurate resolution in the time domain (Kolínský, 2004). Filtered spectra are transformed back to the time domain and a set of harmonic signals with their envelopes is obtained. The local envelope maximum is found for all harmonic components. These maxima can be assigned to different modes of direct surface waves as well as to possible reflected, converted and multi-pathed modes. The ridge corresponding to the fundamental mode is selected in such a manner that the resultant group velocity dispersion curve is smooth regardless of the absolute values of the amplitudes that make up the ridge. Several filter width settings are tested. For the final group velocity determination, we use such a setting, where small change of the filters does not cause any change of the group velocity. Such a group velocity dispersion curve is considered as reliable and filter-independent. For details of this approach see Kolínský (2004); Kolínský and Brokešová (2007) and Kolínský et al. (2011).

\subsection{INVERSION OF GROUP VELOCITY DISPERSION CURVES}

Inversion of group velocity dispersion curves was done using the method described by Kolínský et al. (2014). Inversion is solved by the isometric method (IM). It is a fast algorithm developed by Málek et al. (2005) and tested by Málek et al. (2007). It combines features of several standard inverse methods, particularly the simplex method, Newton's least squares method and simulated annealing. Typical tasks which are effectively solved by the IM are weakly nonlinear problems with tens of parameters.

The forward problem (dispersion curve computation) is solved by the modified ThomsonHaskell matrix method (Proskuryakova et al., 1981). Dispersion curves are calculated for a 1-D medium, formed by horizontal layers with constant values of P-waves $\left(v_{P}\right)$, S-waves $\left(v_{S}\right)$ velocities and densities in each layer above the halfspace. Layer thicknesses are chosen manually by a trial and error approach. The thicknesses gradually increase for deeper layers since the resolution ability of the lower frequencies of surface waves is worse.
The inversion of the dispersion curve is highly non-unique. Different structural models can give similar dispersion curves. To overcome this nonuniqueness of the inversion process, we use the method of Kolínský et al. (2014) and Gaždová et al. (2015). Inversion is computed many times, and mean velocity distribution with its standard deviation is then determined from all runs. In this case, we use 50 inversions. Each single inversion is only weakly constrained by the range of velocities, which can be found in every layer. Hence, the models could be potentially oscillating and complex even having low misfits. The final model calculated as a mean of the 50 models differs qualitatively from any of these 50 models. The product of its misfit and complexity is significantly lower, see Figure 11 in Kolínský et al. (2014) and explanation therein.

The result of the inversion is independent of the starting model. However, by setting a proper starting model which is close to the resulting one, we can save the computational time (Kolínský et al., 2011).

\section{RESULTS}

\subsection{GROUP VELOCITY DISPERSION CURVES}

The Rayleigh and Love wave group velocity dispersion curves of the fundamental mode were determined from the measured seismograms from both quarry blasts (O1 and O2) at MK-net network. The Rayleigh wave dispersion curves were derived from the vertical $(\mathrm{Z})$ component, while the Love ones from the transverse (T) component. Group velocity dispersion curve contains information about the velocity distribution between the source and the station. Only dispersion curves that display similar shape from both blasts are taken into account.

The Rayleigh wave group velocity dispersion curves from the period $0.4 \mathrm{~s}$ to $3.3 \mathrm{~s}$ were obtained at 12 stations. The reliable curves of Love waves were obtained in the period range $0.5-3.0 \mathrm{~s}$ at nine stations. All measured group velocity dispersion curves are presented as thin black lines in Figure 6.

For Rayleigh waves (upper panel of Fig. 6), we can observe one major cluster of curves. This cluster is formed by the curves from stations DVOD, HRAD, KATA, LANC, PODO, PVES and SMOL. All of these stations belong to the area of the Male Karpaty Mountains and the Brezovské Mountains. The quarry Rohožník is located in the same area. Therefore, we establish one mean group velocity dispersion curve for these seven stations, called MKMt curve (bold grey line marked as MKMt in the upper panel of Fig. 6). This MKMt curve represents the mean 1-D model of the area between the quarry and stations. For higher periods (up to $1.6 \mathrm{~s}$ ), this MKMt curve is similar to the curve for DV-Fast model.

The highest group velocities can be observed for two curves belonging to the station ZST. The mean group velocity dispersion curve is called toZST curve (bold grey line marked as toZST in the upper panel of Fig. 6). 


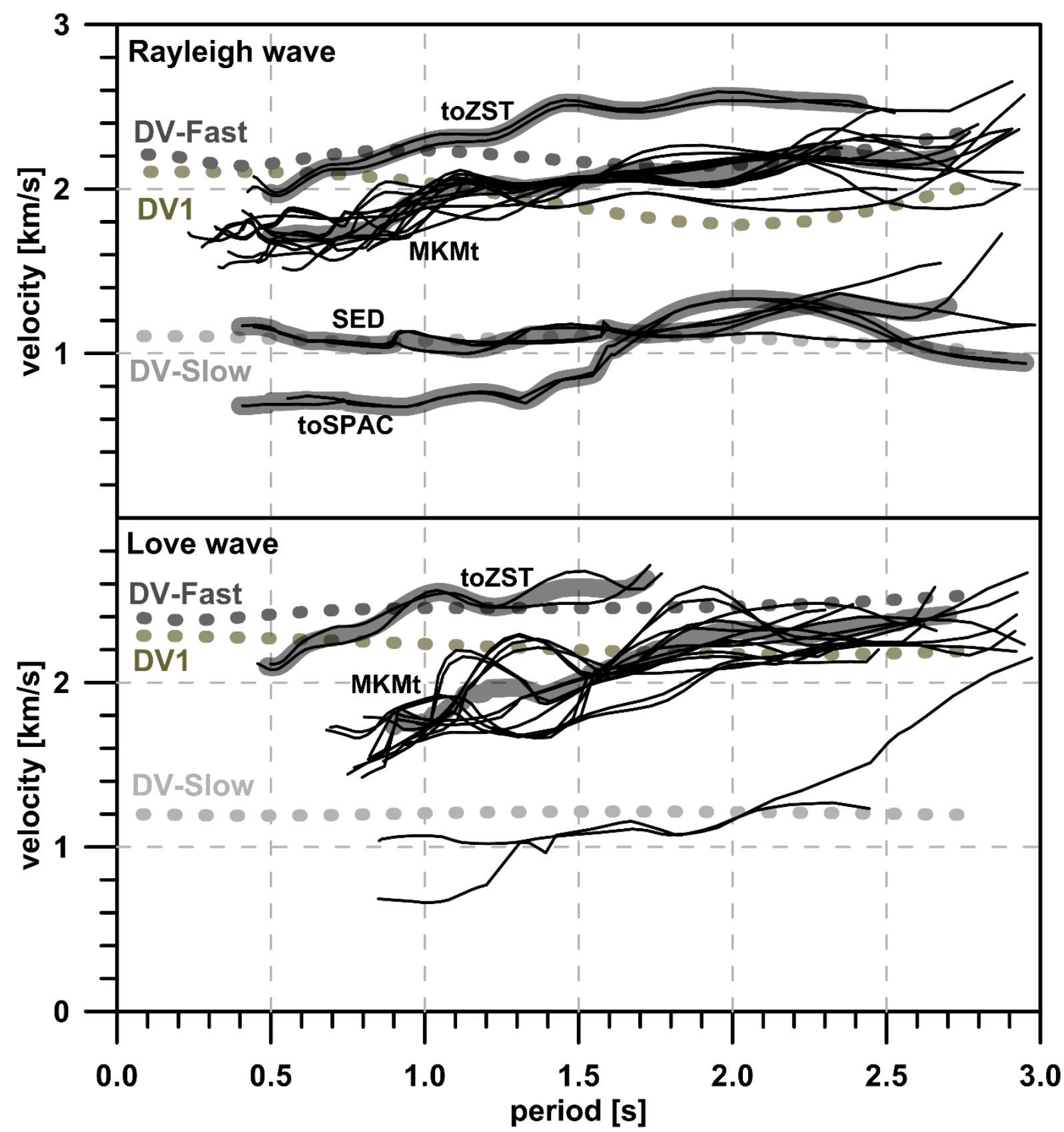

Fig. 6 Measured group velocity dispersion curves of Rayleigh (upper panel) and Love (bottom panel) waves (thin black lines) and mean curves used for inversion denoted as MKMt, toZST, SED and toSPAC (bold grey lines). The grey dashed lines represent theoretical group velocity dispersion curves for DV-Slow, DV1 and DV-Fast velocity models from Figure 3.

The lowest measured Rayleigh wave group velocities for short periods belong to the station SPAC. We can observe group velocities around $0.85 \mathrm{~km} / \mathrm{s}$ for period $0.4-1.3 \mathrm{~s}$ and then velocities increase towards velocities corresponding to the DV-Slow model dispersion curve. Station SPAC is situated inside the Neogene sedimentary basin. Hence, the mean group velocity dispersion curve is called toSPAC curve (bold grey line marked as toSPAC in the upper panel of Fig. 6). In Figure 6, curves for the SPAC station are shown only up to $3 \mathrm{~s}$. The entire measured curve is shown in the upper panel of Figure 10.
Four curves show very similar shape as the curve for DV-Slow model. They belong to stations JABO and BAN. In this case, surface waves propagate from the high-velocity Mesozoic sediments, with quarry Rohožník, into the low-velocity Neogene sediments. Majority of the paths belongs to the Neogene sediments. Accordingly, the mean group velocity dispersion curve is called SED curve (bold grey line marked as SED in the upper panel of Fig. 6).

For the Love wave group velocity (bottom panel of Fig. 6), we can also observe one main cluster of dispersion curves. This cluster is formed by curves from stations BUKO, DVOD, HRAD, KATA, PODO and PVES and mean curve is called MKMt (bold grey 


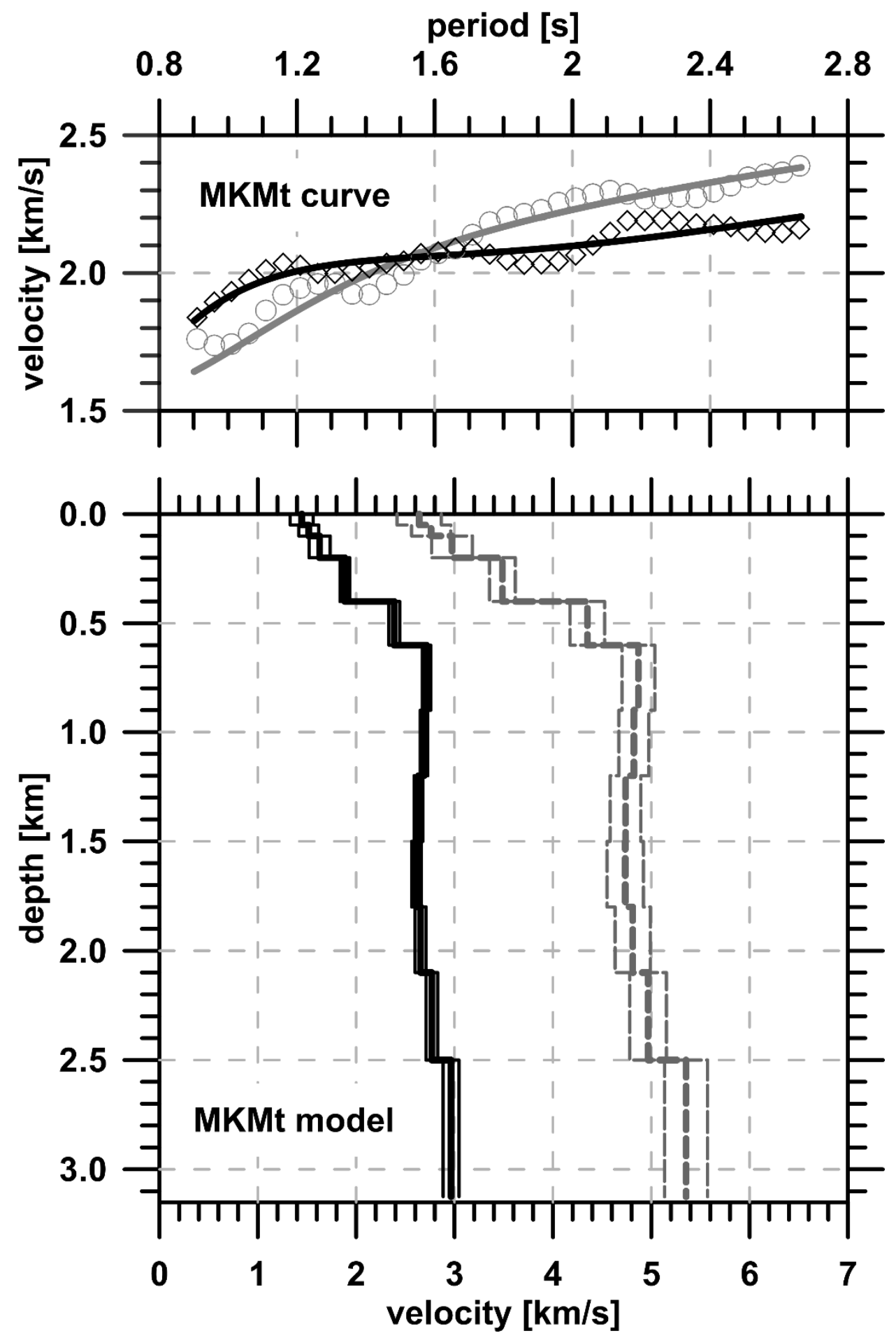

Fig. 7 Results of the inversion of the MKMt curve. The upper panel shows MKMt dispersion curve of Love (grey circles) and Rayleigh (black rhombuses) waves. The grey and black bold lines represent the dispersion curve for the mean inverted structure for Love and Rayleigh waves, respectively. On the bottom panel, there is a resultant MKMt $1 \mathrm{D}$ velocity model. The solid black bold lines represent Swave velocity with the thin solid black lines showing one standard deviation based on 50 inversions. The dashed grey bold line represents the P-wave velocity with one standard deviation shown by thin dashed grey lines. 
line marked as MKMt in the bottom panel of Fig. 6). For the period from 0.9 up to $1.7 \mathrm{~s}$, the MKMt curve has velocities lower than those for DV1 model. From 1.7 to $3.0 \mathrm{~s}$, we can observe velocities between those for models DV1 and DV-Fast.

The highest group velocities for Love waves belong (as well as for Rayleigh waves) to curves for the station ZST. Consequently, we determined the mean group velocity dispersion curve called toZST (bold grey line labeled toZST in the bottom panel of Fig. 6)

The lowest Love wave group velocities were observed only for the station JABO. For the stations BAN and SPAC, it was not possible to determine reliable Love dispersion curves. Because the station JABO is equipped with $1 \mathrm{~s}$ seismometer (Guralp), we could not determine a dispersion curve for longer periods. Thus, we did not estimate a mean Love wave dispersion curve for Neogene sedimentary basin.

For further processing, we have two mean group velocity dispersion curves for both Rayleigh and Love waves (MKMt and toZST curve), which allows us to use joint inversion. Two mean curves were obtained only for the Rayleigh waves (SED and toSPAC curve).

\subsection{1-D VELOCITY MODELS}

\subsubsection{1-D VELOCITY MODELS FROM THE JOINT INVERSION OF RAYLEIGH AND LOVE WAVES}

The MKMt and toZST curves were determined for both Love and Rayleigh waves. This allows us to do a joint inversion of Love and Rayleigh velocity dispersion. This inversion is more robust and reliable than the inversion from single wave group (e.g., Dal Moro and Ferigo, 2011). In the case of a joint inversion, the input data are from both the $\mathrm{Z}$ and $\mathrm{T}$ components.

The joint inversion determines three parameters for each layer: S-wave velocity $v_{S}, \mathrm{P}$-wave velocity $v_{P}$ and density. Because dispersion depends predominantly on $v_{S}$, the other two parameters are constrained. The density is fixed to increase in constant steps with increasing depth. In the uppermost layer the density is set to $2.67 \mathrm{~g} / \mathrm{cm}^{3}$ and increases by $0.006 \mathrm{~g} / \mathrm{cm}^{3}$ in each subsequent layer. The value of the density in the uppermost layer was chosen as an average value of the Mesozoic limestone density in the area of Western Carpathians (Ibrmajer and Suk, 1989). In the halfspace, the density was set as $2.73 \mathrm{~g} / \mathrm{cm}^{3}$, which is the average density of the Mesozoic sediments of Hronicum (Šamajová et al., 2018). Value of $v_{P}$ is constrained by the $v_{P} / v_{S}$ ratio which was set on value $1.81 \pm 0.1$. The value 1.81 was found by the Wadati method described in section 3.1. The inversion is allowed to search for its final $v_{P}$ value in the range of \pm 0.1 from the starting value of 1.81 . The interval for $v_{P} / v_{S}$ ratio was enlarged from the value \pm 0.02 (which is set by Wadati method in section 3.1 from $\mathrm{Pg}$ and $\mathrm{Sg}$ waves) to cover possible variations in larger depth interval estimated by surface wave inversion.
The first layer, with thickness $50 \mathrm{~m}$, had a prescribed $v_{S}=1.4 \pm 0.4 \mathrm{~km} / \mathrm{s}$ for the starting model for the MKMt curve and $v_{S}=1.8 \pm 0.4 \mathrm{~km} / \mathrm{s}$ for the toZST curve.

An 11-layered model with half-space at depth of $2.5 \mathrm{~km}$ was used for the inversion. A detailed description of the method and selection of the proper layered model is described by Kolínský et al. (2014) and Gaždová et al. (2015).

The joint inversion used here allows us to process Love and Rayleigh dispersion curves only when both have the same period range. Hence, the joint inversion is carried out for the period range 0.9 $2.7 \mathrm{~s}$ for MKMt curve and $0.5-1.7 \mathrm{~s}$ for toZST curve.

The result of the MKMt curve joint inversion are shown in Figure 7. The bottom panel represents the mean 1D velocity model, calculated as an average from 50 inversion runs and its standard deviation. The average $v_{S}$ velocities and their deviations are represented by black solid lines; $v_{P}$ parameters are depicted by the grey dashed lines. The upper panel represents MKMt curve of Love (grey circles) and Rayleigh (black rhombuses) waves; solid grey and black lines delineate dispersion curves corresponding to the mean velocity distribution of inverted Love and Rayleigh waves, respectively. The parameters of the resultant MKMt model are provided in Table 2. This model represents the average velocity structure of the area beneath stations BUKO, DVOD, HRAD, KATA, LANC, PODO, PVES and SMOL. All of these stations are situated in the area of the Malé Karpaty Mountains and the Brezovské Mountains, where the prevailing geology structure is formed by Mesozoic sediments covering Tatricum crystalline basement. We can observe an increase of the velocities from the surface down to the depths of $0.9 \mathrm{~km}$. Then, velocities slightly decrease. The minimum of the low-velocity zone is at a depth of $1.8 \mathrm{~km}$ after which the velocities moderately increase to the velocity of the halfspace.

Figure 8 shows results from the joint inversion of Love and Rayleigh waves for toZST curve. The bottom panel shows 1D velocity model of the structure between the Rohožník quarry and the

Table 2 Parameters of the MKMt model.

\begin{tabular}{|c|c|c|c|c|}
\hline $\begin{array}{c}\text { thickness } \\
\text { of layers } \\
{[\mathrm{km}]}\end{array}$ & $\begin{array}{l}\text { depth } \\
{[\mathrm{km}]}\end{array}$ & $\begin{array}{c}\mathrm{VP} \\
{[\mathrm{km} / \mathrm{s}]}\end{array}$ & $\begin{array}{c}\mathrm{VS} \\
{[\mathrm{km} / \mathrm{s}]}\end{array}$ & $\begin{array}{l}\mathrm{VP}_{\mathrm{p}} / \mathrm{V}_{\mathrm{S}} \\
\text { ratio }\end{array}$ \\
\hline 0.05 & 0.05 & 2.64 & 1.45 & 1.83 \\
\hline 0.05 & 0.10 & 2.76 & 1.52 & 1.82 \\
\hline 0.10 & 0.20 & 2.97 & 1.63 & 1.83 \\
\hline 0.20 & 0.40 & 3.49 & 1.89 & 1.85 \\
\hline 0.20 & 0.60 & 4.35 & 2.39 & 1.82 \\
\hline 0.30 & 0.90 & 4.87 & 2.72 & 1.79 \\
\hline 0.30 & 1.20 & 4.82 & 2.69 & 1.79 \\
\hline 0.30 & 1.50 & 4.74 & 2.63 & 1.80 \\
\hline 0.30 & 1.80 & 4.74 & 2.61 & 1.81 \\
\hline 0.30 & 2.10 & 4.81 & 2.66 & 1.81 \\
\hline 0.40 & 2.50 & 4.97 & 2.77 & 1.79 \\
\hline halfspace & halfspace & 5.35 & 2.96 & 1.81 \\
\hline
\end{tabular}




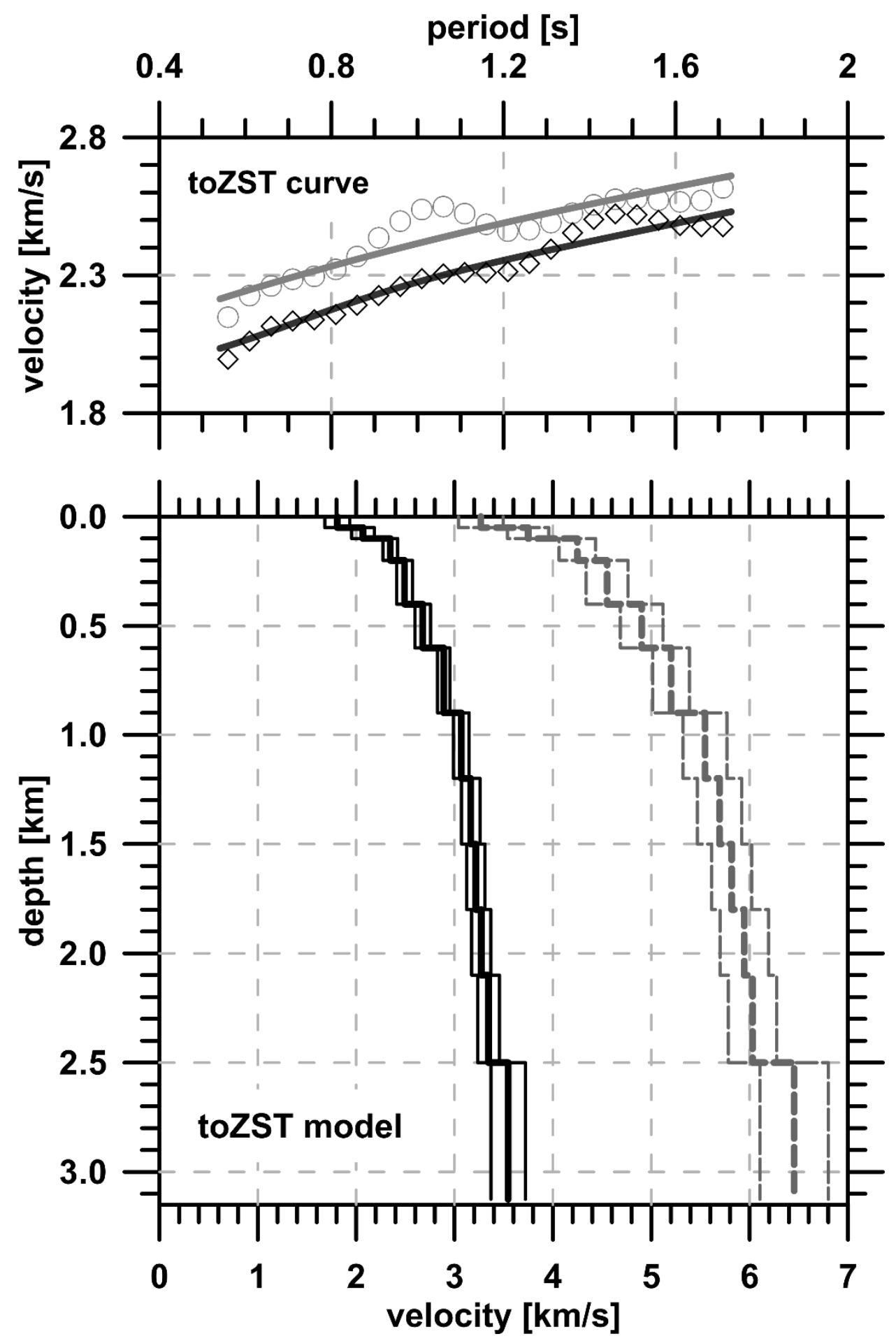

Fig. 8 Results of the inversion of the toZST curve. Lines and symbols are the same as in Figure 7.

ZST station. In this case, toZST model includes both Mesozoic sediments as well as Tatricum crystalline that form the south part of Malé Karpaty Mountains. The model has a continuously increasing velocity with the depth with no low-velocity zone (LVZ).

\subsubsection{1-D VELOCITY MODELS FROM THE INVERSION OF RAYLEIGH WAVES}

Only the Rayleigh wave mean group velocity dispersion curve was found for the stations JABO and BAN (SED curve) and the station SPAC (toSPAC curve). Hence, we provide the inversion of only one wave type in these cases.

In the uppermost layer the density is set to $2.30 \mathrm{~g} / \mathrm{cm}^{3}$ with density increasing by $0.035 \mathrm{~g} / \mathrm{cm}^{3}$ in each subsequent layer and reaching $2.65 \mathrm{~g} / \mathrm{cm}^{3}$ in the halfspace. This range is set according to the variation of the densities of the Neogene and Quaternary sediments of Internal Western Carpathians Neogene (Šamajová et al., 2018). The value of $2.65 \mathrm{~g} / \mathrm{cm}^{3}$ in the halfspace is consistent with the average value for granites and granodiorites in bedrock in the study area 


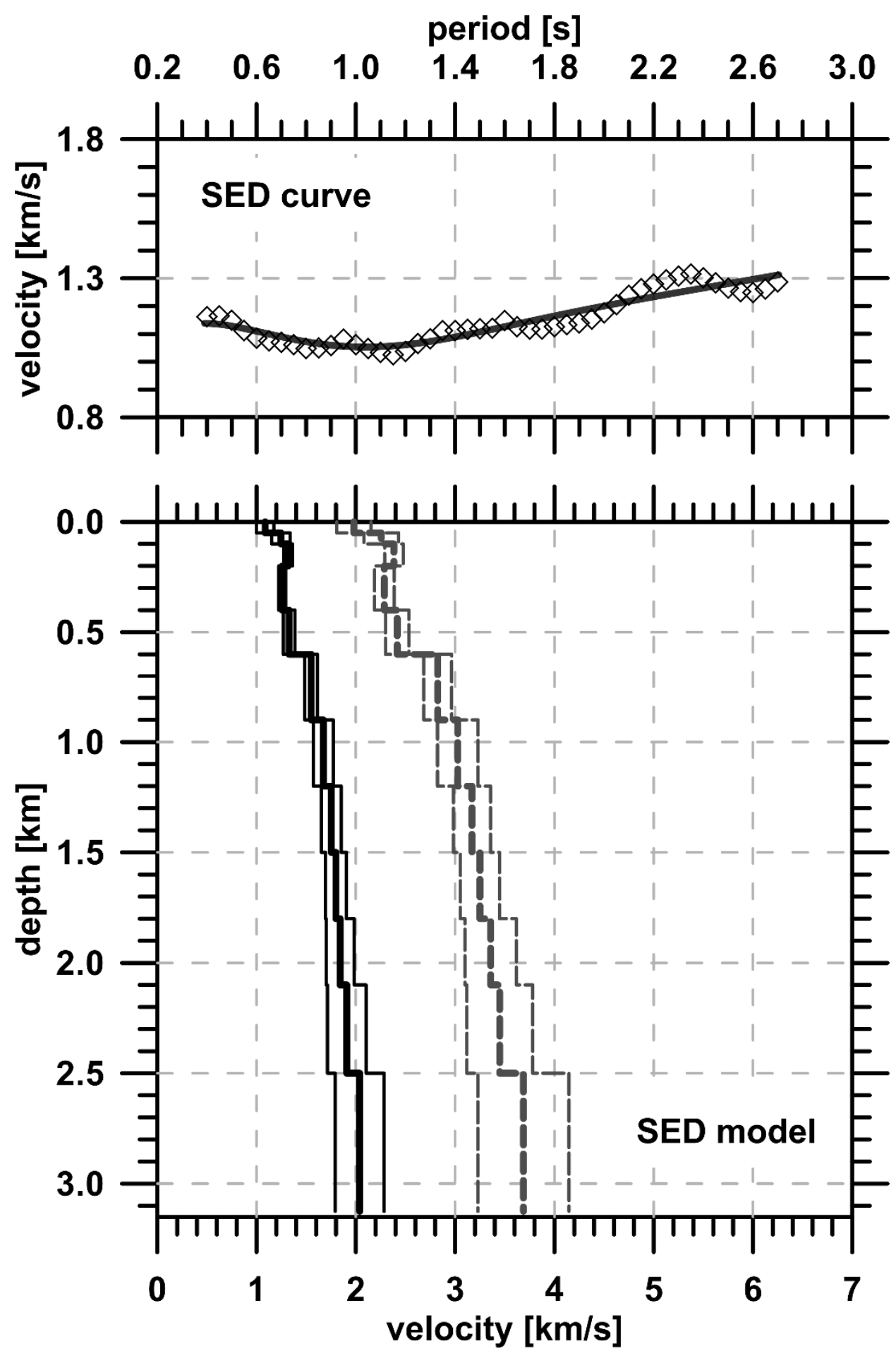

Fig. 9 Results of the inversion of the SED curve. Lines and symbols are as in Figure 7.

(Ibrmajer and Suk, 1989). The value of $v_{P}$ is constrained by the $v_{P} / v_{S}$ ratio (as in case of the joint inversion) $1.81 \pm 0.1$.

The velocity of the first layer, with thickness $50 \mathrm{~m}$, was adjusted as $v_{S}=0.8 \pm 0.4 \mathrm{~km} / \mathrm{s}$ for the starting model for the SED mean curve and $v_{S}=0.6 \pm$ $0.4 \mathrm{~km} / \mathrm{s}$ for the starting value of the toSPAC mean curve.

The same 11-layered model with the half-space at depth of $2.5 \mathrm{~km}$ was used as for the joint inversion.
Figure 9 shows results of inversion for the SED curve. First three layers show velocities increasing with depth. We observe a LVZ around depth of $0.3 \mathrm{~km}$. Below this depth, velocity continuously increases with depth with a significant increase at $0.6 \mathrm{~km}$. This model represents the $1 \mathrm{D}$ velocity model of the area that includes the quarry Rohožník and seismic stations JABO and BAN. In this case, seismic waves travel from the quarry formed by Mesozoic sediments towards a basin filled with slower Neogene sediments. 


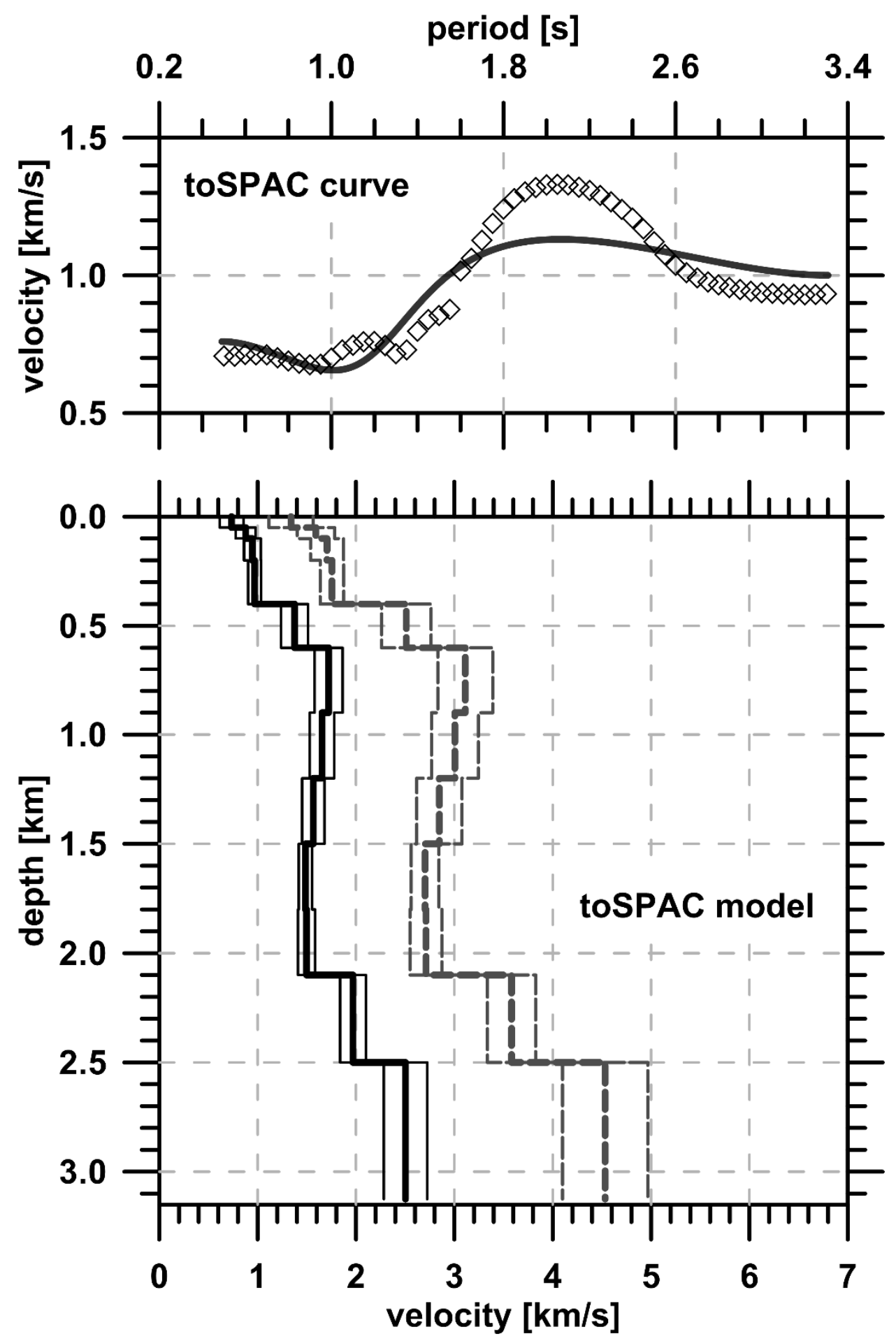

Fig. 10 Results of the inversion of the toSPAC curve. Lines and symbols are the same as that in Figure 7.

Figure 10 shows the inversion results of the toSPAC curve. In this model, we observe significant increases in velocity at depths $0.4 \mathrm{~km}$ and $0.6 \mathrm{~km}$. Each subsequent layer shows a decrease in velocity until a depth of $2.1 \mathrm{~km}$, marking a broad LVZ from 0.9 to $2.1 \mathrm{~km}$. This model, like that for SED, represents a $1 \mathrm{D}$ velocity model of the structure with Mesozoik sediments in the vicinity of the quarry and Neogene sediments in the vicinity of the SPAC station. In the period range 1.6-2.6 s, the inversion represents only general trends of the measured curve. The measured values are significantly higher than the inverted ones. This is caused by the fact, that this profile cannot be, in this particular period range, properly described by 1D velocity model, because approximately half of the profile belongs to the Mesozoic sediments and the second part is in the basin with Neogene sediments. 


\section{DISCUSSION AND CONCLUSIONS}

An accurate velocity model is one of the basic conditions for most seismological investigations, such as precise location of hypocenters and determination of focal mechanisms. Normally, special active seismic experiments using artificial sources and many seismic stations are necessary to sufficiently resolve a model. Such experiments are very expensive. Passive seismic measurements at the stations of permanent local seismic network, which register both earthquakes and man-made blasts, especially quarry blasts, can partially substitute for an active experiment. Determining a velocity model from earthquake recordings is possible in principle, but complicated in practice, because there is a strong trade-off between model parameters and earthquake locations. Model parameters, especially those of near-surface layers, cannot be well resolved using body waves from local earthquakes. Quarry blasts are excellent sources of seismic waves for finding a model because their exact locations are known. However, the surface waves generated by blasts provide information on nearsurface velocity structure, down to several kilometers. Information from earthquakes and quarry blasts should be combined to obtain a complete model.

In this paper, surface waves generated from quarry blasts were used to improve the knowledge of the velocity structure, following a well-known methodology (e.g. Chourak et al., 2003 or Gaždová et al., 2008). The analysis primarily provides information on the shear wave velocity.

The primary result of this study is the MKMt model for the velocity structure. It is based on MKMt dispersion curve, which is calculated as the mean curve for six stations from two blasts. Joint inversion of Rayleigh and Love waves is applied. Because the seismograms are quite complicated, the reliability of the mean curve is higher than that of the curves formed from one or two stations, such as toZST, SED and toSPAC. The model of the velocity structure from the joint inversion is more robust than the model from the inversion of just one surface wave type.

The results presented in this paper are the first step in developing of a new velocity model for the region of the Western Carpathians, which is important from both scientific and practical reasons. In particular, a precise velocity model is important for a better seismic hazard estimation of the nuclear power plant Jaslovské Bohunice.

While knowing the P-wave shallow structure is important to determine better locations and focal mechanisms, the shallow S-wave velocity structure is highly important to understand local effects. The amplification is all due to the shallow S-wave velocity structure. Even an average $v_{S}$ in the upper layers is useful to estimate site amplification (e.g. Seale and Archuleta, 1989; Yang and Sato, 2000; Boaga et al., 2011).

\section{ACKNOWLEDGEMENT}

Authors acknowledge the financial support provided for their work by the long term conceptual development research organization of the Institute of Rock Structure and Mechanics CAS under project No. RVO: 67985891. Authors thank to Dr. Juraj Sekeres and Dr. Dagmar Sekeresova for providing the data from the stations of local seismic network MKnet. Authors have been also supported by the Slovak Foundation Grant VEGA-2/0144/19 and APVV-16-0146. Authors thanks to the project: OP VVV project CzechGeo/EPOS-Sci (CZ.02.1.01/0.0/0.0/16_013/0001800)

\section{REFERENCES}

Bezák, V. (ed.), Broska, I., Ivanička, J., Reichwalder, P., Vozár, J., Polák, M., Havrila, M., Mello, J., Biely, A., Plašienka, D., Potfaj, M., Konečný, V., Lexa, J., Kaličiak, M., Žec, B., Vass, D., Elečko, M., Janočko, J., Pereszlényi, M., Marko, F., Maglay, J. and Pristaš, J.: 2004, Tectonic map of Slovak republic 1:500 000. ŠGÚDŠ, Bratislava, Slovakia.

Bezák, V., Pek, J., Vozár, J., Bielik, M. and Vozár, J.: 2014, Geoelectrical and geological structure of the crust in Western Slovakia. Stud. Geophys. Geod., 58, 3, 473488. DOI: $10.1007 / \mathrm{s} 11200-013-0491-9$

Boaga, J., Vignoli, G. and Cassiani, G.: 2011, Shear wave profiles from surface wave inversion: the impact of uncertainty on seismic site response analysis. J. Geophys. Eng., 8, 2, 162-174. DOI: $10.1088 / 1742-2132 / 8 / 2 / 004$

Chourak, M., Corchete, V., Badal, J., Seron, F. and Gomez, F.: 2003, Imaging of the near-surface shear-wave velocity structure of the Granada Basin (Southern Spain). Bull. Seismol. Soc. Am. 93, 1, 430-442. DOI: $10.1785 / 0120010243$

Dal Moro, G. and Ferigo, F.: 2011, Joint analysis of Rayleigh and Love wave dispersion for near-surface studies: issues, criteria and improvements. J. Appl. Geophys., 75, 3, 573-589.

DOI: $10.1016 /$ j.jappgeo.2011.09.008

Di Giulio, G., Cornou, C, Ohrnberger, M., Wathelet, M. and Rovelli, A.: 2006, Deriving wavefield characteristics and shear-velocity profiles from two-dimensional small-aperture arrays analysis of ambient vibrations in a small-size alluvial basin, Colfiorito, Italy. Bull. Seismol. Soc. Am., 96, 5, 1915-1933.

DOI: $10.1785 / 0120060119$

Dziewonski, A., Bloch, S. and Landisman, M.: 1969, A technique for the analysis of transient seismic signals. Bull. Seismol. Soc. Am., 59, 1, 427-444.

ESI SAS (Earth Science Institute of the Slovak Academy of Sciences): 2004, National Network of Seismic Stations of Slovakia. Deutsches GeoForschungsZentrum GFZ. Other/Seismic Network. DOI: 10.14470/FX099882

Fojtíková, L., Vavryčuk, V., Cipciar, A. and Madarás, J.: 2010, Focal mechanisms of micro-earthquakes in the Dobrá Voda seismoactive area in the Malé Karpathy Mts. (Little Carpathians), Slovakia. Tectonophysics, 492, 1-4, 213-229. DOI: 10.1016/j.tecto.2010.06.007

Fojtíková, L., Kristeková, M., Málek, J., Sokos, E., Csicsay, K. and Zahradník, J.: 2016, Quantifying capability of a local seismic network in terms of locations and focal 
mechanism solutions of weak earthquakes. J. Seismol., 20, No. 1, 93-106.

DOI 10.1007/s10950-015-9512-1

Gaždová, R., Kolínský, P., Málek, J. and Vilhelm, J.: 2008, Shear wave velocities inferred from surface wave dispersion beneath the Príbram array in the Czech Republic. Acta Geodyn. Geomater., 5 (151), 247-255.

Gaždová, R., Kolínský, P., Vilhelm, J. and Valenta, J.: 2015, Combining surface waves and common methods for shallow geophysical survey. Near Surf. Geophys., 13, 1, 19-32. DOI: 10.3997/1873-0604.2014039

Hók, J., Kováč, M., Pelech, M., Pešková, I., Vojtko, R. and Králiková, S.: 2016, The Alpine tectonic evolution of the Danube Basin and its northern periphery (southwestern Slovakia). Geol. Carpath., 67, 5, 495505. DOI: $10.1515 /$ geoca-2016-0031

Ibrmajer, J. and Suk, M. (eds): 1989, Geofyzikální obraz ČSSR. Academia, Prague, 354 pp., (in Czech).

Jechumtálová, Z. and Bulant, P.: 2014, Effects of 1-D versus 3 -D velocity models on moment tensor inversion in the Dobrá Voda area in the Little Carpathian region, Slovakia. J. Seismol., 18, 3, 511-531. DOI: $10.1007 / \mathrm{s} 10950-014-9423-6$

Kolínský, P.: 2004, Surface wave dispersion curves of Eurasian earthquakes: the SVAL Program. Acta Geodyn. Geomater., 1, No. 2 (134), 165-185.

Kolínský, P. and Brokešová, J.: 2007, The Western Bohemia uppermost crust shear wave velocities from Love wave dispersion. J. Seismol., 11, 1, 101-120. DOI: 10.1007/s10950-006-9040-0

Kolínský, P., Málek, J. and Brokešová, J.: 2011, Shear wave crustal velocity model of the western Bohemian Massif from Love wave phase velocity dispersion. J. Seismol., 15, 1, 81-104. DOI: $10.1007 / \mathrm{s} 10950-010-9209-4$

Kolínský, P., Valenta, J. and Málek, J.: 2014, Velocity model of the Hronov-Poŕíći Fault Zone from Rayleigh wave dispersion. J. Seismol., 18, 3, 617-635. DOI: $10.1007 / \mathrm{s} 10950-014-9433-4$

Málek, J., Horálek, J. and Janský, J.: 2005, One-dimensional qP-wave velocity model of the upper crust for the West Bohemia/Vogtland earthquake swarm region. Stud. Geophys. Geod., 49, 4, 501-524.

Málek, J., Růžek, B. and Kolář, P.: 2007, Isometric method: efficient tool for solving non-linear inverse problems. Stud. Geophys. Geod., 51, 4, 469-490.

Marko, F., Andriessen, P.A.M., Tomek, Č., Bezák, V., Fojtíková, L., Bošanský, M., Piovarči, M. and Reichwalder, P.: 2017, Carpathian shear corridor - A strike-slip boundary of an extruded crustal segment. Tectonophysics, 703-704, 119-134. DOI: $10.1016 /$ j.tecto.2017.02.010

Novotný O., Málek J. and Boušková A.: 2016, Wadati method as a simple tool to study seismically active fault zones: a case study from the WestBohemia/Vogtland region, central Europe. Stud. Geophys. Geod., 60, 2, 248-267. DOI: $10.1007 / \mathrm{s} 11200-015-1206-1$
Plašienka, D., Michalík, J., Kováč, M., Gross, P. and Putiš, M.: 1991, Paleotectonic evolution of the Malé Karpaty Mts - an overview. Geol. Carpath., 42, 4, 195-208.

Plašienka, D., Grecula, P., Putiš, M., Kováč, M. and Hovorka, D.: 1997, Evolution and structure of the Western Carpathians: an overview. In: Grecula, M., Hovorka, D. and Putiš, M. (Eds.): Geological Evolution of the Western Carpathians. Miner. Slov. Monograph. Bratislava, 1-24.

Polák, M., Plašienka, D., Kohút, M., Bezák, V., Filo, I., Olšavský, M., Havrila, M., Buček, S., Maglay, J., Elečko, M., Fordinál, K., Nagy, A., Hraško, L., Németh, Z., Ivanička, J. and Broska, I.: 2011, Geological map of the Malé Karpaty Mts. (scale 1:50000).

Proskuryakova, T.A., Novotný, O. and Voronina, E.V.: 1981, Studies of the Earth's structure by the surface wave method (Central Europe) (Izuchenie stroeniya Zemli metodom poverkhnostnykh voln (Tsentral'naya Evropa). Nauka, Moscow 1981, (in Russian).

Šamajová, L., Hók, J., Bielik, M. and Pelech, O.: 2018, Deep contact of the Bohemian Massif and Western Carpathians as seen from density modelling. Geol. Carpath., 69, 6, 545-557. DOI: $10.1515 /$ geoca-2018-0032

Seale, S.H. and Archuleta, R.J.: 1989, Site amplification and attenuation of strong ground motions. Bull. Seismol. Soc. Am., 79, 6, 1673-1696.

Wadati, K.: 1933, On the travel time of earthquake waves. Part. II. The Geophysical Magazine (Tokyo), 7, 101111.

Wathelet, M., Guillier, B., Roux, P., Cornou, C. and Ohrnberger, M.: 2018, Rayleigh wave threecomponent beamforming: signed ellipticity assessment from high-resolution frequencywavenumber processing of ambient vibration arrays. Geophys. J.. Int., 215,1, 507-523. DOI: $10.1093 / \mathrm{gji} / \mathrm{ggy} 286$

Wathelet, M., Jongmans, D., Ohrnberger, M. and BonnefoyClaudet, B.: 2008, Array performances for ambient vibrations on a shallow structure and consequences over Vs inversion. J. Seismol., 12, 1-19.

DOI: $10.1007 / \mathrm{s} 10950-007-9067-\mathrm{x}$

Yang, J. and Sato, T., 2001: Interpretation of seismic vertical amplification observed at an array site. Bull. Seismol. Soc. Am., 90, 2, 275-285. DOI: $10.1785 / 0119990068$ 